\title{
Construction of a biological rhythm assessment scale for children
}

\author{
Construção de uma escala de avaliação do ritmo biológico para crianças
}

\author{
Thierry Berny, ${ }^{1}$ Karen Jansen, ${ }^{1}$ Taiane de Azevedo Cardoso, ${ }^{1,2}$ Thaíse Campos Mondin, ${ }^{1}$ Ricardo Azevedo da Silva, ${ }^{1}$ \\ Luciano Dias de Mattos Souza, ${ }^{1}$ Cristian Patrick Zeni, ${ }^{3}$ Flavio Kapczinski, ${ }^{2,4}$ Vera Figueiredo ${ }^{1}$
}

\begin{abstract}
Introduction: Biological rhythm is associated with the level of alertness, cognitive performance and mood of the individuals. Its regularity is essential to preserve good health and quality of life.

Objective: To present the steps for the construction of the scale entitled Biological Rhythm Interview of Assessment in Neuropsychiatry - Kids (BRIAN-K), designed to measure biological rhythm disruptions in Brazilian children and adolescents.

Methods: Items were developed following the adult version of the scale. Analysis of the psychometric characteristics of the scale was based on the responses of 373 parents/caregivers of school age children ( 7 and 8 years old).

Results: A theoretical model of 17 items with the purpose of evaluating four domains (sleep, activities, social rhythm and eating pattern) was determined using exploratory factor analysis (EFA) and via identification of a general factor. The psychometric properties of the BRIAN-K showed favorable properties.

Conclusion: Only two items needed to be rewritten. Further studies are needed to investigate the instrument's adequacy to different age groups and additional evidence of validity and reliability.
\end{abstract}

Keywords: BRIAN, biological rhythm, circadian rhythm, construction of scale, kids.

\section{Resumo}

Introdução: O ritmo biológico está associado ao nível de alerta, desempenho cognitivo e humor dos indivíduos. Sua regularidade é essencial para preservar uma boa saúde e qualidade de vida. Objetivo: Apresentar as etapas de construção da escala intitulada Biological Rhythm Interview of Assessment in Neuropsychiatry Kids (BRIAN-K), criada para medir disrupturas do ritmo biológico em crianças e adolescentes brasileiros.

Métodos: Os itens foram desenvolvidos seguindo a versão adulta da escala. A análise das características psicométricas da escala se baseou nas respostas de 373 pais/cuidadores de crianças em idade escolar (7 e 8 anos).

Resultados: Um modelo teórico de 17 itens, com o objetivo de avaliar quatro domínios do ritmo biológico (sono, atividades, ritmo social e padrão alimentar) foi determinado usando análise fatorial exploratória (AFE) e pela identificação de um fator geral. As propriedades psicométricas da BRIAN-K mostraram-se satisfatórias.

Conclusão: Apenas dois itens precisaram ser reescritos. São necessários mais estudos para investigar a adequação do instrumento a diferentes faixas etárias e evidências adicionais de validade e confiabilidade.

Descritores: BRIAN, ritmo biológico, ritmo circadiano, construção de escala, crianças.

\footnotetext{
${ }^{1}$ Universidade Católica de Pelotas, Pelotas, RS, Brazil. ${ }^{2}$ McMaster University, Hamilton, ON, Canada. ${ }^{3}$ University of Texas Health Science Center at Houston, Houston, TX, USA. ${ }^{4}$ Universidade Federal do Rio Grande do Sul (UFRGS), Porto Alegre, RS, Brazil.

Submitted Jul 10 2017, accepted for publication Nov 242017.

Suggested citation: Berny T, Jansen K, Cardoso TA, Mondin TC, Silva RA, Souza LD, et al. Construction of a biological rhythm assessment Scale for children. Trends Psychiatry Psychother. 2018;40(1):53-60. http://dx.doi.org/10.1590/2237-6089-2017-0081
} 


\section{Introduction}

Rhythm is the repetition or alternation of elements, often with defined intervals in between them. ${ }^{1}$ Biological changes that are repeated at regular intervals (rhythm), such as the levels of potassium ions in a cell, secretion of hormones, sense of orientation, body temperature, sleep/wake cycle, menstrual cycle, regular food intake, etc., are defined as biological rhythms. Such changes are differentiated or grouped based on a period of duration that serves as a reference. ${ }^{1,2}$ Rhythms in physiological oscillations that repeat every 24 hours are known as circadian rhythms.1-3 The importance of biological rhythm can be observed in specific oscillations of brain waves or heartbeats, which are used to distinguish between life and death, as well as between good health and disease. ${ }^{1}$

Biological rhythm disturbance has been associated with mood symptoms and, consequently, with increased risk of relapses in bipolar disorder (BD) and major depressive disorder in adults. ${ }^{3}$ Furthermore, biological rhythm impairment in adults has been associated with poor functioning and quality of life. ${ }^{4}$ Therefore, it is essential to have an assessment instrument for kids, to allow a better understanding of the reactions and the effects that this disturbance may have on our body and mental health in children.

Reliable instruments to evaluate all the properties associated with biological rhythms are scarce; however, there are some related to specific domains. Among those, two scales have been adapted for use in Brazil: (1) Puberty and Phase Preference, for the evaluation of sleep/wake rhythm in children ${ }^{5}$; and (2) Social Rhythm Metric-17, for the evaluation of social rhythm in adults. ${ }^{6}$ Both were used to assess domains associated with biological rhythms (sleep and social rhythm, respectively).

To this end, the Biological Rhythm Interview of Assessment in Neuropsychiatry (BRIAN) was used for the clinical evaluation of biological rhythm disturbance experienced by adults with BD. ${ }^{7}$ The instrument was originally developed in English. Later it was translated into Brazilian Portuguese, Spanish and Italian. ${ }^{8}$ The BRIAN scale evaluates four domains of biological rhythm and assesses the difficulty in maintaining such rhythm. BRIAN was created for adults with BD and was soon expanded to the general population due to its focus on a complete understanding of the individuals. According to Grandin et al., there is evidence of changes in biological rhythms in individuals with a mood disorder. ${ }^{3}$ Accordingly, the assessment of biological rhythms is important to better understand such disorder. In addition to its importance in the field of psychopathology, there is great interest in researching this construct in the general population. Therefore, the development of a scale to evaluate biological rhythms in children also seems relevant, as it will allow an investigation of risk factors for the development of mental disorders in children.

The objective of the present study was to present the stages for the construction of BRIAN - Kids (BRIAN-K).

\section{Methods}

\section{Sample and data collection}

Twenty public schools were selected by systematic random sampling. All the children who fulfilled the inclusion criteria, as well as their primary caregivers, were invited to participate in the study. Inclusion criteria were being a regular student at the selected schools, and being aged 7 and 8 years. Exclusion criteria were inability of the child or the caregiver to understand or answer the instruments due to a medical condition or severe disability.

A team of experts composed of four psychologists from Universidade Católica de Pelotas (UCPel), in Pelotas, southern Brazil, a child psychiatrist and two other psychiatrists were responsible for the development of the BRIAN-K. One of the experts had participated in the construction of the scale validated for adults. The operationalization of this construct was investigated by four of these researchers.

The theoretical analysis of the items was conducted by a group of Brazilian experts (two psychologists, two psychiatrists, a neuropsychologist and a specialist in Brazilian Portuguese language). An experimental version of the BRIAN-K was presented for expert consultation through a form used to analyze the clarity, appropriateness and relevance of the items. With regards to relevance, the evaluators were asked to determine whether the items could adequately measure the proposed dimensions (apparent validity). To determine whether the items were understandable, 20 parents/ caregivers were interviewed in a dialogue format. ${ }^{9}$ These subjects were randomly selected from the database of the original research project entitled "Healthy childhood in context: a proposal for a multidisciplinary study." The study protocol was approved by the research ethics committee of UCPel (protocol no. 843.526). The first author conducted individual interviews with parents/caregivers in their dwellings. With respect to the characteristics of this subsample, there was a prevalence of biological mothers (90\%) aged 25 to 67 years $($ mean $=34.4$; standard deviation $[S D]=10.52)$, and a mean of $9.4(S D=3.49)$ years of schooling. 
All the 373 protocols were subjected to psychometric analysis. Sample size was based on the minimum size required for factor analysis, which is usually 10 subjects per item. ${ }^{10}$ School children between the ages of 7 (49.1\%) and 8 years (50.9\%), mostly males (50.7\%), attending afternoon classes $(68.4 \%)$ in municipal schools in the city of Pelotas, state of Rio Grande do Sul, southern Brazil, participated in the study after agreement was obtained from the parents/caregivers by signing a free and informed consent form. The age of the parents/caregivers ranged between 18 and 77 years (mean $=36.01$; $S D=9.90$ ), with a mean of $8.97(S D=3.26)$ years of schooling.

\section{Data analysis}

Initially, construct validity was evaluated by means of exploratory factor analysis defined to verify how well the scale measured up the proposed psychological construct. Each item was analyzed considering the proposed construct and it was considered valid whenever allocated to the corresponding theoretical model with over $80 \%$ agreement between the evaluators. ${ }^{11}$ To complete the stage of psychometric analysis, reliability validation was performed in terms of internal consistency, assessed via Cronbach's alpha.

\section{Results}

\section{Construct operationalization}

While searching for instruments that measured the properties of biological rhythms in children, the authors found scales to assess eating pattern, time, and quality of sleep; however, none of these instruments would consider the construct of interest. Therefore, the authors decided to develop a scale for children based on the BRIAN scale for adults using their experience in applying it, reports from the target population, clinical observations, findings from previous studies on biological rhythms, and their knowledge in psychopathology and child development. Each item of the adult version corresponded to an item in the children's version. The domains were the same.

According to Pasquali, multiple criteria should be considered for the development of an assessment scale. ${ }^{10}$ Some of them were used for the construction of the BRIAN-K scale, namely: each item should evaluate only one behavior; only a single idea should be expressed in each item; each item should be easily understood by the target population; the repetition of terms in the same item should be avoided; the items should cover the full range of behaviors being measured.

Twenty items remained from the original scale, except the item that investigated the predominant rhythm. Other changes were made in order to adjust the development context for children. For instance, items that referred to work were adapted to school situations. Some items had to be rephrased. The scale had both a Brazilian Portuguese version and an English version, and they were evaluated by a panel of experts fluent in both languages. Changes were made, and after a consensus between the experts was reached, a preliminary version of the scale was applied to children undergoing treatment for mood disorders at the outpatient clinic of the University of Texas at Houston.

The final version of the BRIAN-K consisted of 17 items for the evaluation of four aspects: sleep (items 1 to 5 ); activities (items 6 to 9); social rhythm (items 10 to 13 ); eating pattern (items 14 to 17 ). The scale has been designed to assess how often the child has problems keeping the regularity of the circadian rhythm. Parents or a caregiver answered the items of the scale corresponding to the child's behavior in the last 15 days. This 17 -item instrument was rated using a Likert scale ranging from $0-3$, where $0=$ not at all, $1=$ seldom, 2 = sometimes, 3 = often.

Three other items were included in the scale to measure the predominant rhythm. Two of them were measured using a Likert scale (1 to 4 ), with 1 = morning, 2 = afternoon, 3 = night, 4 = no particular shift; the third item offered the following options: $1=$ never, 2 = seldom, 3 = often, 4 = always.

\section{Theoretical analysis of the scale items}

Here, the experts suggested that some items should be rewritten, as shown in Appendix 1. For the other items, the sentence structure was modified, from "Difficulties in..." to "How difficult it is for the child to..." In the study of relevance, the experts considered item 4 ("What degree of difficulty does the child have in 'disconnecting' while at rest?") as not pertaining to the original dimension (sleep); half of them associated it with the construct of activities. In their evaluation of clarity and understanding of the items, the parents/ caregivers considered item 4 confusing and also suggested that three items should be rewritten. Those suggestions were considered and changes were made, as shown in Appendix 1.

\section{Psychometric analysis of the items}

Initially, a principal component analysis (PCA) was performed to obtain evidence of factorability of the correlation matrix of 17 items. The statistic of sampling adequacy of Kaiser-Meyer-Olkin (KMO) and Bartlett's sphericity test were calculated. The statistical KMO turned out to be equal to 0.906, while Barlett's test was statistically significant $\left(X^{2}=1823.480 ; \mathrm{df}=136\right.$; 
$\rho>0.001)$. For the method of eigenvalue $>1$, the four components accounted for $55.016 \%$ of the variance. The same number of components was displayed in the sedimentation chart. Finally, principal axis factoring $(\mathrm{PAF})$, with oblimin rotation, showed correlation between the factors, ranging from 0.283 (eating pattern and sleep) to 0.622 (activities and social rhythm). Table 1 presents the factor loads of the 17 items (in short), the eigenvalues, the explained variance and the a coefficients for each factor, considering the theoretical model. It should be observed that item 4 was not consistent with the original proposal and item 17 had no significant loading on any of the factors.

After another analysis, items 4 and 17 were excluded for being considered statistically insignificant. The results are displayed in Table 2, where all items showed factorial loads $\geq 0.306$ and were grouped into four dimensions of the theoretical model. However, internal consistency estimates for the sleep and eating pattern domains decreased. Therefore, these two items were rephrased.

PAF was used to check whether the 17 items could be grouped into a single factor and therefore produce a total score for biological rhythm. Table 3 shows that the items displayed satisfactory factor loads, with values ranging from 0.373 to 0.689 , suggesting that these factors have contributed to the assessment of the construct.

The internal consistency of the scale was computed using Cronbach's alpha and the estimate was considered acceptable (0.871), indicating inter-relatedness of the items within the test. ${ }^{12}$ Therefore, the 17 items are reliable for the assessment of the construct. If a low alpha is due to poor correlation between items, then an item (or items) should be discarded. In this case, as the estimate of reliability increases, the accuracy of the measurement decreases.

\section{Discussion}

The construction of the BRIAN-K scale followed the model proposed by Pasquali, as it covered the theoretical framework that underlies the construct of interest, the preparation of items, and the theoretical and psychometric analysis of the items. ${ }^{10}$ The construct was defined, its properties were observed, its dimensionality was known, following the theoretical

Table 1 - Composition of factors and factor loads for each item

\begin{tabular}{|c|c|c|c|c|}
\hline \multirow[b]{2}{*}{ Items } & \multicolumn{4}{|c|}{ Factors } \\
\hline & $\begin{array}{c}\mathbf{F 1} \\
\text { Activities }\end{array}$ & $\begin{array}{c}\mathbf{F 2} \\
\text { Eating pattern }\end{array}$ & $\begin{array}{c}\text { F3 } \\
\text { Sleep }\end{array}$ & $\begin{array}{c}\text { F4 } \\
\text { Social rhythm }\end{array}$ \\
\hline 7. Difficulties completing habitual tasks & 0.752 & 0.066 & -0.103 & -0.013 \\
\hline 9. Difficulties completing tasks at usual time & 0.622 & 0.087 & 0.073 & -0.063 \\
\hline 6. Difficulties completing school tasks & 0.571 & 0.032 & 0.049 & -0.002 \\
\hline $\begin{array}{l}\text { 8. Difficulties keeping rhythm and persistence in physical } \\
\text { activities }\end{array}$ & 0.433 & -0.033 & 0.085 & -0.040 \\
\hline 17. Difficulties consuming moderate amounts of stimulants & 0.292 & 0.246 & 0.066 & -0.077 \\
\hline 15. Difficulties eating daily meals & -0.086 & 0.748 & 0.054 & -0.062 \\
\hline 16. Difficulties eating the same amount of food & 0.143 & 0.540 & -0.034 & 0.044 \\
\hline 14. Difficulties sticking with the meal schedule & 0.051 & 0.429 & 0.137 & -0.172 \\
\hline 2. Difficulties getting out of bed after wakening up & -0.100 & 0.106 & 0.784 & 0.065 \\
\hline 1. Difficulties waking up at the same time most of the days & 0.188 & -0.015 & 0.635 & 0.071 \\
\hline $\begin{array}{l}\text { 5. Difficulties going to sleep at the same time with the others } \\
\text { in the house }\end{array}$ & 0.027 & 0.046 & 0.487 & -0.252 \\
\hline 3. Difficulties feeling rested with the number of hours of sleep & 0.122 & -0.019 & 0.403 & -0.208 \\
\hline $\begin{array}{l}\text { 10. Difficulties relating to other people in the house at } \\
\text { appropriate times }\end{array}$ & -0.054 & 0.058 & -0.053 & -0.742 \\
\hline $\begin{array}{l}\text { 12. Difficulties syncing own daily routine with other people in } \\
\text { the house }\end{array}$ & 0.053 & 0.124 & 0.090 & -0.593 \\
\hline $\begin{array}{l}\text { 13. Difficulties giving time and paying attention to other people } \\
\text { in the house }\end{array}$ & 0.151 & 0.065 & -0.031 & -0.416 \\
\hline 4. Difficulties of the child "disconnecting" while at rest & 0.132 & -0.101 & 0.292 & -0.341 \\
\hline 11. Difficulties using electronics in a balanced way & 0.230 & -0.071 & 0.091 & -0.323 \\
\hline Eigenvalues & 5.710 & 1.390 & 1.213 & 1.040 \\
\hline Total variance $(\%)$ & 33.588 & 8.179 & 7.133 & 6.115 \\
\hline Cronbach's alpha & 0.735 & 0.664 & 0.767 & 0.695 \\
\hline
\end{tabular}

56 - Trends Psychiatry Psychother. 2018;40(1) 
model of the BRIAN scale for adults. The items were built and selected by a qualified panel of judges, based on previous instruments in the literature (adult version), target population reports and results obtained from research on biological rhythms. ${ }^{13}$ In addition, the experience and the technical training of the researchers in psychopathology and child development should also be considered. The applicable criteria on the number of items and the elaboration of items were observed.

The assessment of the experts on relevance suggested that the items were suitable for the domains related to the theoretical model, as only a single item showed low correlation. Semantically, the parents/caregivers found this specific item difficult to understand and suggested

Table 2 - Composition of four factors and factor loads for each item

\begin{tabular}{|c|c|c|c|c|}
\hline \multirow[b]{2}{*}{ Items } & \multicolumn{4}{|c|}{ Factors } \\
\hline & $\begin{array}{c}\text { F1 } \\
\text { Activities }\end{array}$ & $\begin{array}{c}\text { F2 } \\
\text { Sleep }\end{array}$ & $\begin{array}{c}\text { F3 } \\
\text { Eating patterns }\end{array}$ & $\begin{array}{l}\text { F4 } \\
\text { Social rhythm }\end{array}$ \\
\hline 1. Difficulties waking up at the same time most of the days & & -0.639 & & \\
\hline 2. Difficulties getting out of bed after wakening up & & -0.815 & & \\
\hline 3. Difficulties feeling rested with the amount of hours of sleep & & -0.388 & & \\
\hline $\begin{array}{l}\text { 5. Difficulties going to sleep at the same time with the others } \\
\text { in the house }\end{array}$ & & -0.473 & & \\
\hline 6. Difficulties completing school tasks & 0.571 & & & \\
\hline 7. Difficulties completing habitual tasks & 0.74 & & & \\
\hline $\begin{array}{l}\text { 8. Difficulties keeping rhythm and persistence in physical } \\
\text { activities }\end{array}$ & 0.407 & & & \\
\hline 9. Difficulties completing tasks at the usual time & 0.626 & & & \\
\hline $\begin{array}{l}\text { 10. Difficulties relating to other people in the house at } \\
\text { appropriate times }\end{array}$ & & & & -0.761 \\
\hline 11. Difficulties using electronics in a balanced way & & & & -0.306 \\
\hline $\begin{array}{l}\text { 12. Difficulties syncing own daily routine with other people in } \\
\text { the house }\end{array}$ & & & & -0.628 \\
\hline $\begin{array}{l}\text { 13. Difficulties giving time and paying attention to other people } \\
\text { in the house }\end{array}$ & & & & -0.436 \\
\hline 14. Difficulties sticking with the meal schedule & & & 0.413 & \\
\hline 15. Difficulties eating daily meals & & & 0.819 & \\
\hline 16. Difficulties eating the same amount of food & & & 0.501 & \\
\hline
\end{tabular}

Table 3 - Factor loads of all items for unifactorial distribution

\begin{tabular}{lc}
\hline & F1 \\
Items & BRIAN-K \\
\hline 9. Difficulties completing tasks at the usual time & 0.689 \\
12. Difficulties syncing own daily routine with other people in the house & 0.676 \\
5. Difficulties going to sleep at the same time with the others in the house & 0.622 \\
7. Difficulties completing habitual tasks & 0.602 \\
3. Difficulties feeling rested with the number of hours of sleep & 0.568 \\
1. Difficulties waking up at the same time most of the days & 0.555 \\
4. Difficulties of the child "disconnecting" while at rest & 0.554 \\
10. Difficulties relating to other people in the house at appropriate times & 0.548 \\
6. Difficulties completing school tasks & 0.546 \\
14. Difficulties sticking with the meal schedule & 0.543 \\
17. Difficulties consuming moderate amounts of stimulants & 0.514 \\
11. Difficulties using electronics in a balanced way & 0.494 \\
13. Difficulties giving time and paying attention to other people in the house & 0.492 \\
2. Difficulties getting out of bed after wakening up & 0.486 \\
8. Difficulties keeping rhythm and persistence in physical activities & 0.450 \\
15. Difficulties eating daily meals & 0.437 \\
16. Difficulties eating the same amount of food & 0.373 \\
\hline
\end{tabular}

BRIAN-K = Biological Rhythm Interview of Assessment in Neuropsychiatry - Kids. 
some writing changes in three other items, aiming to improve the instrument. The main author accepted the relevant suggestions given by the experts and parents/ caregivers.

The study of dimensionality of the 17 items of the BRIAN-K identified four factors (activities, eating pattern, sleep and social rhythm), confirming the consistence with the theoretical model for adults. Items 4 and 17 had problems in the factorial distribution and were not consistent with the original factor; item 4 was pointed out because of the use of the word "disconnect," considering that it was misunderstood by the experts of the target population as there was divergence on its inclusion in either the sleep or activities domains. Although item 17 showed no problems in the theoretical analysis, the author made an attempt to include it in the original domain (eating pattern). However, two items were maintained due to their significant load factor in a unifactorial model; in other words, they contributed to the total score of the instrument. Therefore, its psychometric features should be considered in further studies and with different populations.

The study of the unifactorial structure revealed the possibility of a total score of biological rhythm. The general factor proved to be appropriate, considering the significant loads of the 17 items for this domain. The results obtained are in agreement with those proposed by Pasquali, who suggested approximately 20 items as the ideal number to cover the semantic extension of a construct. ${ }^{10}$

The present study was able to construct an assessment scale for biological rhythm in children. The instrument achieved satisfactory psychometric characteristics. The limitation of the study was the age of the target population ( 7 to 8 years), which did not allow the normative standardization of the instrument;

Table 4 - Improvement of items in the BRIAN-K experimental version

\begin{tabular}{|c|c|c|}
\hline Items of the experimental version & $\begin{array}{l}\text { Reason for } \\
\text { alteration }\end{array}$ & $\begin{array}{l}\text { Improved items with suggestions from experts } \\
\text { (in italics) }\end{array}$ \\
\hline $\begin{array}{l}\text { 3. What degree of difficulty does the child have in } \\
\text { feeling rested with the number of hours of sleep } \\
\text { (subjective feeling and normal performance in daily } \\
\text { tasks such as playing games and school activities)? }\end{array}$ & Clarity & $\begin{array}{l}\text { How difficult it is for the child to feel rested with the } \\
\text { number of hours of sleep (having normal performance in } \\
\text { everyday tasks such as playing and performing tasks at } \\
\text { school)? }\end{array}$ \\
\hline $\begin{array}{l}\text { 4. What degree of difficulty does the child have in } \\
\text { "disconnecting" while at rest (when there are no } \\
\text { tasks)? }\end{array}$ & Ambiguity & How difficult it is for the child to calm down while at rest? \\
\hline $\begin{array}{l}\text { 5. What degree of difficulty does the child have in } \\
\text { sleeping at the same time as the others in the } \\
\text { house? }\end{array}$ & Clarity & $\begin{array}{l}\text { How difficult it is for the child to sleep at the same time } \\
\text { as the people in the house? }\end{array}$ \\
\hline $\begin{array}{l}\text { 6. What degree of difficulty does the child have in } \\
\text { completing the school tasks? }\end{array}$ & Clarity & $\begin{array}{l}\text { How difficult it is for the child to complete the school } \\
\text { tasks? }\end{array}$ \\
\hline $\begin{array}{l}\text { 7. What degree of difficulty does the child have in } \\
\text { completing the habitual tasks (finishing play, cleaning } \\
\text { up toys and bedroom)? }\end{array}$ & Clarity & $\begin{array}{l}\text { How difficult it is for the child to complete the habitual } \\
\text { tasks (doing school tasks, cleaning up toys after play, } \\
\text { etc.)? }\end{array}$ \\
\hline $\begin{array}{l}\text { 9. What degree of difficulty does the child have in } \\
\text { completing tasks at the usual time? }\end{array}$ & Clarity & $\begin{array}{l}\text { How difficult it is for the child to complete the tasks } \\
\text { (school tasks, cleaning up the bedroom, etc.) at the } \\
\text { usual time? }\end{array}$ \\
\hline $\begin{array}{l}\text { 10. What degree of difficulty does the child have in } \\
\text { relating and communicating with the social activities } \\
\text { of people in the house at appropriate times? }\end{array}$ & Clarity & $\begin{array}{l}\text { How difficult it is for the child to communicate with } \\
\text { friends and family members at appropriate times? }\end{array}$ \\
\hline $\begin{array}{l}\text { 12. What degree of difficulty does the child have in } \\
\text { syncing own daily routine with other people (family } \\
\text { members, neighbors, and friends)? }\end{array}$ & Clarity & $\begin{array}{l}\text { How difficult it is for the child to maintain the routine } \\
\text { adopted by other people in the house (family members, } \\
\text { neighbors, and friends)? }\end{array}$ \\
\hline $\begin{array}{l}\text { 17. What degree of difficulty does the child have in } \\
\text { consuming moderate amounts of stimulants (cocoa } \\
\text { and non-alcoholic beverages) or candies? }\end{array}$ & $\begin{array}{l}\text { Clarity; close } \\
\text { to the original } \\
\text { domain }\end{array}$ & $\begin{array}{l}\text { How difficult it is for the child to consume moderate } \\
\text { amounts of stimulants (cocoa, coffee, non-alcoholic } \\
\text { beverages) or sweets, regardless of the period of the } \\
\text { day? }\end{array}$ \\
\hline
\end{tabular}

BRIAN-K = Biological Rhythm Interview of Assessment in Neuropsychiatry - Kids. 
in addition, measures of criterion were not made. The use of the BRIAN-K scale should cover other age groups and clinical groups. Also necessary are studies on construct validity through confirmatory factor analysis and convergent and discriminant validity analysis. Other evidence of reliability should be investigated, and standards should be established, to assess and therefore improve the quality of the instrument.

This study aimed to construct a scale for the scientific community to evaluate an important construct that can be considered an indicator of mental health, or a predictor of future mental disorders among children and adolescents. The literature has suggested an association between biological rhythm disturbance and the presence of depressive and bipolar disorders in adults. In that sense, it would be relevant to investigate whether the same relationship may also affect children, characterizing biological rhythm disturbance as a risk factor.

\section{Acknowledgements}

Fundação de Amparo à Pesquisa do Estado do Rio Grande do Sul (FAPERGS) and Conselho Nacional de Desenvolvimento Científico e Tecnológico (CNPq).

\section{Disclosure}

No conflicts of interest declared concerning the publication of this article.

\section{References}

1. García DMJ, Hernández RL. Circadian Rhythms in cancer patients. Psicogente. 2014;17:352-64.

2. Mondin TC, Cardoso TA, Jansen K, Spessato BC, Souza LDM, Silva RA. Effects of cognitive psychotherapy on the biological rhythm of patients with depression. J Affect Disord. 2014;155:142-8.

3. Grandin LD, Alloy LB, Abramson LY. The social zeitgeber theory, circadian rhythms, and mood disorders: Review and evaluation. Clin Psychol Rev. 2006;26:679-94.

4. Cudney LE, Frey BN, Streiner DL, Minuzzi L, Sassi RB. Biological rhythms are independently associated with quality of life in bipolar disorder. Int J Bipolar Disord. 2016;4:9.

5. Finimundi M, Barin I, Bandeira D, Souza DO. Validación de la escala de ritmo circadiano - ciclo vigilia / sueño para adolescentes. Rev Paul Pediatr. 2012;30:409-14.

6. Schimitt RL, Hidalgo MPL. Translation into Portuguese and content validation of the Social Rhythm Metric-17 (SRM-17). Rev Psiquiatr Rio Gd Sul. 2009;31:120-7.

7. Giglio LM, Magalhães PV, Andreazza AC, Walz JC, Jakobson $L$, Rucci $P$, et al. Development and use of a biological rhythm interview. J Affect Disord. 2009;118:161-5.

8. Moro MF, Carta MG, Pintus M, Pintus E, Melis R, Kapczinski F, et al. Validation of the Italian Version of the Biological Rhythms Interview of Assessment in Neuropsychiatry (BRIAN): some considerations on its screening usefulness. Clin Pract Epidemiol Ment Health. 2014;10:48-52.

9. Skevington SM, Bradshaw J, Saxena S. Selecting national items for the WHOQOL: conceptual and psychometric considerations. Soc Sci Med. 1999;48:473-87.

10. Pasquali L. Instrumentação psicológica: fundamentos e práticas. Porto Alegre: Artmed; 2010.

11. Pasquali L. Psicometria: teoria e aplicações. Brasília: UnB; 1998.

12. Pasquali L. Psicometria: teoria dos testes na psicologia e na educação. Petrópolis: Vozes; 2003.

13. Coluti MZO, Costa-Alexandre NM, Milani D. Construction of measurement instruments in the area of health. Cienc Saude Coletiva. 2015;20:925-36.

\section{Correspondence:}

Karen Jansen

Rua Gonçalves Chaves, 373/224, Centro

96015-560 - Pelotas, RS - Brazil

Tel./Fax: +55 (53) 21288404, +55 (53) 991489066

E-mail: karen.jansen@ucpel.edu.br 


\section{Appendix 1}

BIOLOGICAL RHYTHM INTERVIEW ASSESSMENT IN NEUROPSYCHIATRY - VERSÃO KIDS (BRIAN-K)

Considerando a rotina da sua família, assinale a opção que melhor descreve a conduta da criança nos últimos 15 dias.
(0) nenhuma
(1) pouca
(2) bastante
(3) muita

SONO

1. Qual é o grau de dificuldade da criança para acordar no mesmo horário na maioria dos dias?

2. Qual é o grau de dificuldade da criança para sair da cama depois de despertar?

3. Qual é o grau de dificuldade da criança para sentir-se descansada com o número de horas que dorme (ter desempenho normal em tarefas diárias como brincar e realizar atividades na escola).

4. Qual é o grau de dificuldade da criança para se acalmar nos momentos de descanso?

5. Qual é o grau de dificuldade da criança para dormir no mesmo horário das pessoas que mora? ATIVIDADES

6. Qual é o grau de dificuldade da criança para terminar as atividades que faz na escola?

7. Qual é o grau de dificuldade da criança para terminar as atividades habituais (fazer a tarefa da escola, guardar os brinquedos depois de brincar, etc.)?

8. Qual é o grau de dificuldade da criança para manter o ritmo e persistência em atividades físicas (como praticar um esporte, fazer atividade física na escola)?

9. Qual é o grau de dificuldade da criança para cumprir suas tarefas (da escola, arrumar o quarto, etc.) no horário habitual?

\section{SOCIAL}

10. Qual é o grau de dificuldade da criança para se comunicar com amigos e familiares em horários adequados?

11. Qual é o grau de dificuldade da criança para usar de forma equilibrada aparelhos eletrônicos como videogame, TV, computador, etc. (sem que isso prejudique seu contato com as pessoas com quem convive, ou gaste um número de horas desproporcionais em relação aos seus outros afazeres)?

12. Qual é o grau de dificuldade da criança para manter a rotina adotada pelas pessoas com quem convive (familiares, vizinhos, amigos)?

13. Qual é o grau de dificuldade da criança para disponibilizar tempo e atenção para as pessoas com quem convive (familiares, vizinhos, amigos)?

\section{ALIMENTAÇÃo}

14. Qual é o grau de dificuldade da criança para manter o horário das refeições (café da manhã, almoço, lanche e jantar)?

15. Qual é o grau de dificuldade da criança para realizar todas refeições (café da manhã, almoço, lanche e jantar)?

16. Qual é o grau de dificuldade da criança para manter a mesma quantidade de alimento ingerido regularmente?

17. Qual é o grau de dificuldade da criança para consumir, com moderação, estimulantes (achocolatado, café, coca-cola) ou doces, independente do turno?

\section{RITMO PREDOMINANTE}

Considerando a rotina da sua família, assinale a opção que melhor descreve a conduta da criança nos últimos 12 meses.
(1) manhã
(2) tarde
(3) noite
(4) não há turno específico

18. Em qual parte do dia você tem a impressão de que a criança se sente mais disposta e ativa?

19. Em qual parte do dia você tem a impressão de que a criança está mais concentrada e produtiva?
(1) nunca
(2) raramente
(3) quase sempre
(4) sempre

20. A criança tem trocado o dia pela noite?

\begin{tabular}{|l|l|l|l|l|}
\hline $\mathbf{0}$ & $\mathbf{1}$ & $\mathbf{2}$ & $\mathbf{3}$ \\
\hline 0 & 1 & 2 & 3 \\
\hline 0 & 1 & 2 & 3 \\
\hline 0 & 1 & 2 & 3 \\
\hline 0 & 1 & 2 & 3 \\
\hline 0 & 1 & 2 & 3 \\
\hline $\mathbf{0}$ & $\mathbf{1}$ & $\mathbf{2}$ & $\mathbf{3}$ \\
\hline 0 & 1 & 2 & 3 \\
\hline 0 & 1 & 2 & 3 \\
\hline 0 & 1 & 2 & 3 \\
\hline 0 & 1 & 2 & 3 \\
\hline 0 & 1 & 2 & 3 \\
\hline 0 & 1 & 2 & 3 \\
\hline 0 & 1 & 2 & 3 \\
\hline 0 & 1 & 2 & 3 \\
\hline 0 & 1 & 2 & 3 \\
\hline 0 & 1 & 2 & 3 \\
\hline 0 & 1 & 2 & 3 \\
\hline 0 & 1 & 2 & 3 \\
\hline 0 & 1 & 2 & 3 \\
\hline 0 & 1 & 2 & 3 \\
\hline 0
\end{tabular}

